\title{
Candidatus phytoplasma fraxini related (16S rRNAVII) strain associated with date yellows disease in Iran
}

\author{
Maryam Ghayeb Zamharir ${ }^{1} \cdot$ Seyed Mahdi Shetab Boshehri ${ }^{2} \cdot$ Yadollah Khajehzadeh $^{2}$
}

Received: 16 August 2016 / Accepted: 20 October 2016/Published online: 25 October 2016

(C) Australasian Plant Pathology Society Inc. 2016

\begin{abstract}
Phytoplasma was detected in date palm trees (Phoenix dactylifera) displaying symptoms of yellowing disease by nested polymerase chain reaction using 16 SrRNA gene universal primers of phytoplasmas. Sequence identities of $98 \%$ were found to several isolates of 'Candidatus Phytoplasma fraxini' (Ash yellows group, 16SrVII group).
\end{abstract}

Keywords Phytoplasma - Date palm · Ash yellows group · Yellows

Iran is one of the leading date producing and exporting countries in the world. The main production areas in Iran are Hormozgan (21.6\%), Khusistan (17.6\%), Bushehr (13.4\%), Beluchistan (12.2\%), Fars (12.3\%) and

Maryam Ghayeb Zamharir zamharir2005@yahoo.com

Plant Disease Department, Iranian Research Institute of Plant protection, AREEO, Tehran PO Box 19395-1454, Iran

2 Plant protection Department, Khozestan Agricultural and Natural Resources Research and Education Centre, AREEO, Ahvaz, Iran
Kerman $(21.1 \%)$ provinces. Various pathogens such as fungi, viruses and phytoplasma severely affect palm tree cultivation worldwide (Harries 1977; Howard 1983, Abdullah Samir et al. 2010). Natural occurrence of leaf yellows disease on several date (Phoenix dactylifera) plants were observed in gardens at Khusistan province, Iran, during winter of 2013-15. The symptoms were leaf yellows, tiny narrow leaves and leaf drying (Fig. 1). Due to date economic importance for the country and Khusistan province, the identification of the causal agent of the leaf yellows disease of date was necessary. To investigate the possibility of a phytoplasma causal agent, the total DNA was isolated from leaf tissue of 25 symptomatic and 10 healthy date plants following the protocol of Doyle and Doyle (1990). The initial PCR was performed using P1/P7 universal primers specific to the 16S rRNA Gene (Schneider et al. 1995). Further, nested PCR was carried out with primers R16F2n/R16R2 (Gundersen and Lee 1996) employing the initial PCR product as the template.

Agarose gel electrophoresis of nested PCR products obtained with the $16 \mathrm{~S}$ rRNA-gene-specific primers resulted in the expected size DNA fragments of $1.2 \mathrm{~kb}$, from infected plant samples but not from healthy samples. The 1.2-kb amplicons obtained from the nested PCR was cloned, sequenced and the data deposited in GenBank (Accession number KX347967). BLAST search analysis of KX347967 revealed $98 \%$ sequence 
Fig. 1 Plant showing elongated internodes and abnormal branches (a). Plant leaves with yellows (b) and date leaf drying (c)
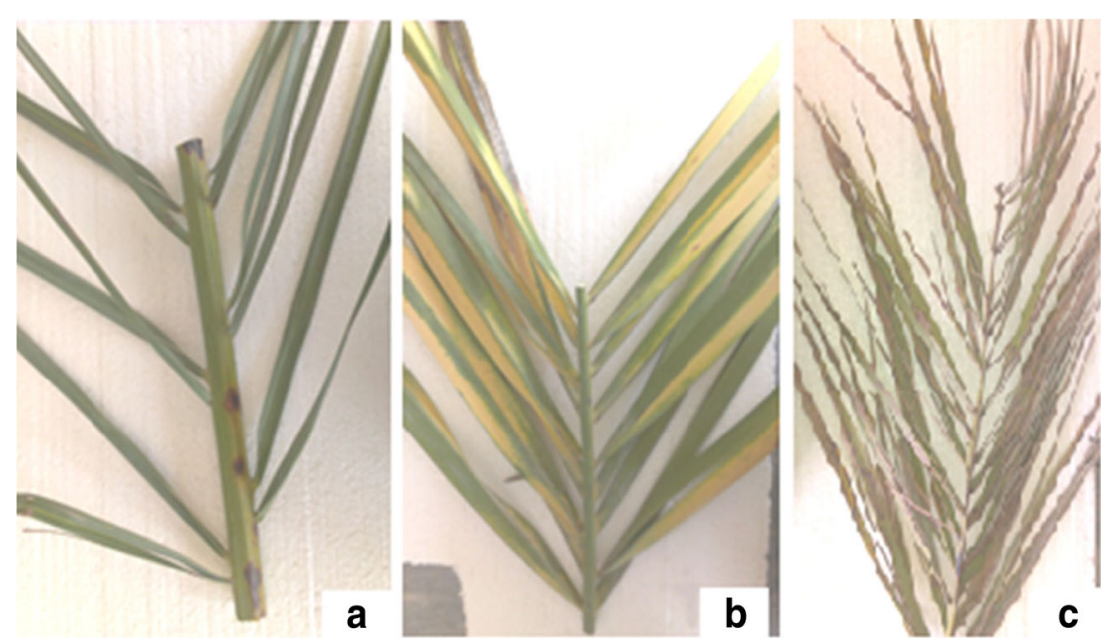

similarity with the 16S rRNA gene of 'Candidatus Phytoplasma fraxini' isolate L1-09, L3-09, Cajica Straw CR1, 'Magnolia grandiflora' phytoplasma strain Magn1 (Accession numbers KP324846, KP324845, KJ910297, KJ093444) respectively, belonging to the $16 \mathrm{~S}$ rVII group.

Phylogenetic analysis of the phytoplasma isolates using molecular evolutionary genetics analysis (MEGA) 6.0 tool (Tamura et al. 2007) also showed a close relationship with isolates of ash yellows 'Candidatus Phytoplasma fraxini’ (16SrVII) group (Fig. 2).

Date trees are known to be affected by phytoplasmas including lethal yellowing (16SrIV-A), Texas phoenix palm decline (16SrIV-D) (Howard 1983; Schuiling et al. 1992) and Al-Wijam decline (16SrI) (El-Zayat et al. 2002), however to the best of our knowledge, the association of 'Candidatus Phytoplasma fraxini' with yellows disease of date palm is the first report of this kind from Iran.
Fig. 2 Phylogenetic tree constructed by neighbour-joining method of 16S rRNA gene sequences from date palm phytoplasma strains (P2) and reference phytoplasmas from GenBank. 'Ca. P.' stands for 'Candidatus Phytoplasma species'. The numbers on the branches are bootstrap (confidence) values of 100 replicates

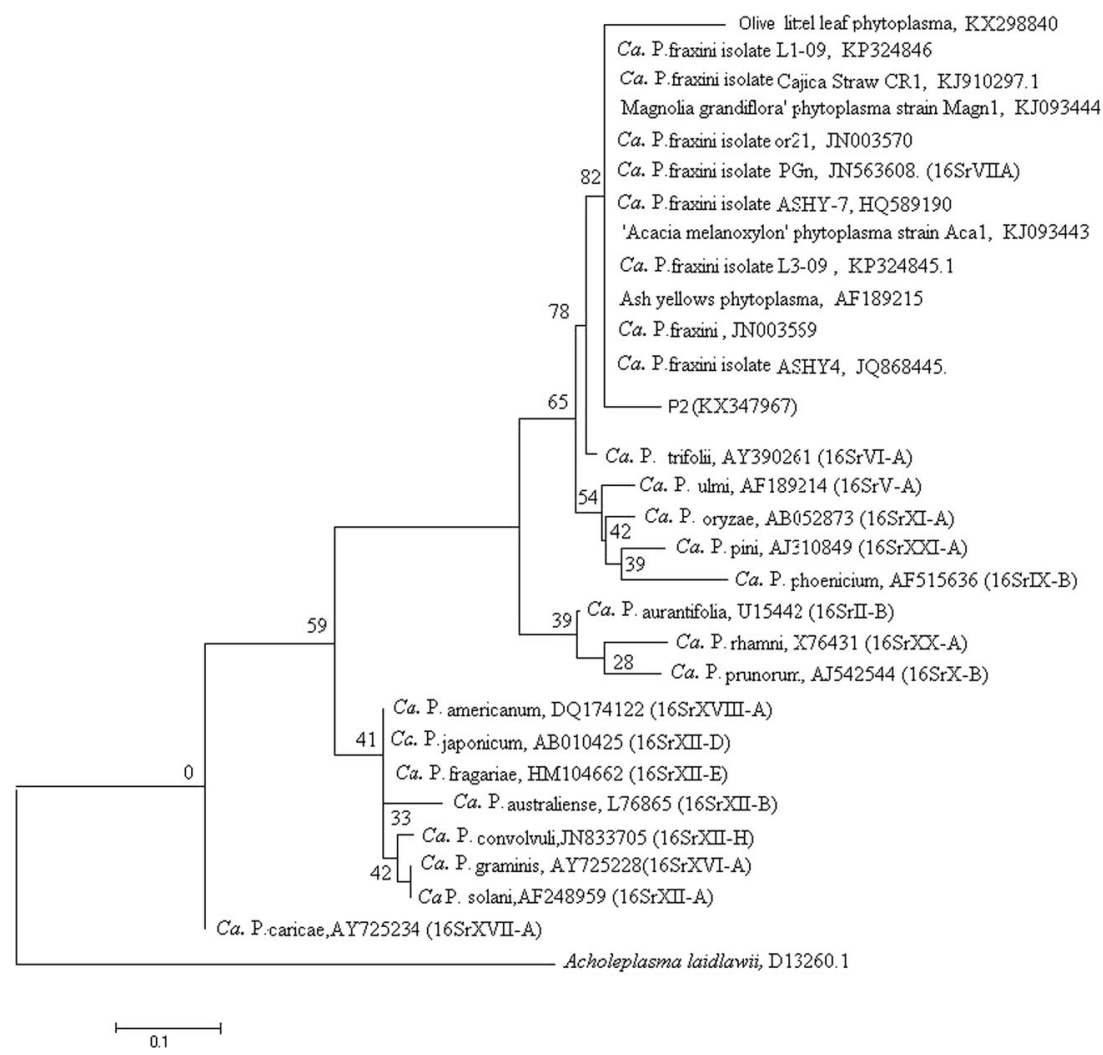




\section{References}

Abdullah Samir K, Lopez Lorca LV, Jansson HB (2010) Diseases of date palms (Phoenix dactylifera L.). Basrah Journal for Date Palm Researches 9(2):1-43

Doyle JJ, Doyle JL (1990) Isolation of plant DNA from fresh tissue. Focus 12 N 1:13-15

El-Zayat MM, Shamloul AM, Abdulsalam KS, Djerbi M, Hadidi A (2002) Molecular detection and identification of a prokaryotic pathogen associated with Al-Wijam declining disease of date palms in Saudi Arabia. Arab J Biotech 5(2):193-206

Gundersen DE, Lee IM (1996) Ultrasensitive detection of phytoplasmas by nested-PCR assays using two universal primer pairs. Phytopathol Mediterr 35:144-151

Harries HC (1977) In: Plant health and quarantine in international transfer of genetic resources (Ed. by Hewitt, W.B.; Chiarappa, L.). CRC Press, Cleveland, USA
Howard FW (1983) World distribution and possible geographical origin of palm lethal yellowing disease and its vectors. FAO Plant Protection Bulletin 31:101-113

Schneider B, Seemüller E, Smart C, Kirkpatrick C (1995) Phylogenetic classification of plant pathogenic mycoplasmalike organisms or phytoplasmas. In: Razin R, Tully JG (eds) Molecular and diagnostic procedures in Mycoplasmology. Academic Press, San Diego, USA, pp. $369-380$

Schuiling M, Kaiza DA, Mpunami A (1992) Lethal disease of coconut palm in Tanzania. II. History, distribution and epidemiology. Oléagineux 47:516-522

Tamura K, Dudley J, Nei M, Kumar S (2007) MEGA4: molecular evolutionary genetics analysis (MEGA) software version 4.0. Mol Biol Evol 24:1596-1599 